\title{
Lazada, Shopee Atau Tokopedia? Sebuah Preferensi Lokapasar oleh Mahasiswa-Pekerja Di Area Tangerang Raya
}

\author{
Chandra Fitra Arifianto ${ }^{1}$,dan Yuli Endah Pratiwi ${ }^{2}$ \\ ${ }^{1,2}$ Universitas Pamulang, Indonesia \\ *e-mail: dosen01177@unpam.ac.id
}

\begin{abstract}
ABSTRAK : Persaingan lokapasar (marketplace) di Indonesia semakin hebat dalam memikat pengguna aplikasi mereka. Oleh karena itu, penelitian ini dilakukan untuk melihat preferensi mahasiswa-pekerja di Tangerang Raya dalam menentukan 3 lokapasar (marketplace), yaitu: Lazada, Shopee dan Tokopedia, yang dinilainya lebih baik. Tinjauan literatur pada penelitian ini bersumber dari Svobodová dan Rajchlová (2020) tentang identifikasi perilaku pembelian secara daring (online shopping) yang terdiri atas 13 komponen yaitu: ulasan dan keluhan, sertifikasi dan keamanan, iklan dan komunikasi, harga produk, situs web (website), faktor organisasi, deskripsi produk, metode pembayaran, jaringan toko, transportasi, dan diskon. Ini merupakan sebuah penelitian survei deskriptifyang menggunakan55 mahasiswa-pekerja sebagai responden dalam menjawab kuesioner yang diajukan oleh peneliti. Persentase sederhana digunakan untuk analisis data. Temuan penelitian menunjukkan bahwa Tokopedia memiliki ratarata penilaian jawaban responden yang tertinggi. Sehingga dapat diasumsikan bahwa Tokopedia lebih unggul dalam memenuhi 13 komponen untuk mengidentifikasi perilaku pembelian secara daring.Selain itu, terungkap juga bahwa komponen ulasan dan keluhan serta transportasi menjadi prioritas bagi konsumen dalam melakukan pembelian secara daring.
\end{abstract}

Kata Kunci: Marketplace, Mahasiswa-pekerja, Online shop, Perilaku pembelian daring

ABSTRACT : Marketplace competition in Indonesia is increasingly fierce in attracting users of their applications. Therefore, this study was conducted to examine the preferences of students and workers in the Greater Tangerang area in determining 3 marketplaces, namely: Lazada, Shopee and Tokopedia, which he considered better. The literature review in this study was sourced from Svobodová and Rajchlová (2020) regarding the identification of online buying behavior which consists of 13 components, namely: reviews and complaints, certification and security, advertising and communication, product prices, websites, organizational factors, product descriptions, payment methods, store chains, transportation, and discounts. This is a descriptive survey study using 55 student-workers as respondents in answering the questionnaire submitted by the researcher. Simple percentages were used for data analysis. The research findings show that Tokopedia has the highest average respondent's answer assessment. So it can be assumed that Tokopedia is superior in fulfilling the 13 components to identify online buying behavior. In addition, it was also revealed that the components of reviews and complaints as well as transportation are priorities for consumers in making online purchases.

Keyword: Marketplace, Student-workers, Online shop, Online buying behavior 


\section{PENDAHULUAN}

Seiring kemajuan teknologi yang dirasakan oleh kita saat ini, perubahan gaya hidup pun juga terjadi. Pemanfaatan gawai tidak hanya sebatas untuk sarana komunikasi saja. Lebih dari itu, berbagai media dukungan yang berbentuk perangkat lunak telah mendukung kecepatan dan keakuratan gawai dalam mengakses data. Bahkan, penyedia layanan telekomunikasi dan informasi turut juga gencar menawarkan berbagai keunggulan dari teknologi terkini yang mereka punya. Asupan digitalisasi yang diberikan telah memanjakan kita untuk selalu menjadi terkini dan eksis. Inilah yang menjadi sebuah gaya hidup digital, dimana menempatkan praktik digital dalam dunia sosial dan spasial.

Gaya hidup digital ini oleh (Hatuka et al., 2021) mengacu pada hubungan dinamis antaratiga dimensi, yaitu: status sosial ekonomi pengguna, tempat tinggal pengguna yang terfokus pada karakteristik sosiospasial lokal, dan praktik digital pengguna. Ketiga dimensi ini mempengaruhi gaya hidup digital yang dikembangkan dan dibudayakan oleh masyarakat, terutama di perkotaan. Oleh karena itu, tidak dapat ditolak jika masyarakat semakin membuka diri atas keagungan 'kehidupan baru' tersebut. Dengan berbagai kemudahan, mereka dapat mencari informasi tanpa ada batasan tempat dan waktu. Sehingga gaya hidup digital telah menjadi kebiasaan baru yang semakin hari semakin banyak pengikutnya.

Kebiasaan baru tersebut niscaya telah mengubah perilaku masyarakat, terutama generasi muda. Hanum (2021) mencatat pernyataan Kementerian Komunikasi dan Informatika bahwa pengguna ponsel pintar di Indonesia saat ini telah mencapai 167 juta orang atau $89 \%$ dari total penduduk Indonesia. Pendorongnya tidak lain ialah semakin murahnya tarif internet yang tersedia. Terlebih lagi, karena generasi muda semakin terbuka terhadap informasi dan teknologi, penggunaan gawai perlu mengikuti perkembangan teknologi terkini. Tidak sedikit dari mereka yang mengeluarkan uang dengan jumlah besar hanya untuk dapat merasakan kemajuan teknologi. Namun dibalik itu semua, ada beberapa yang memanfaatkan kemajuan teknologi untuk mendapatkan pundi-pundi uang. Jadi gawai yang mereka beli dapat dianggap sebagai modal untuk berusaha.

Disisi lainnya pertumbuhan lokapasar daring menyeimbangi perkembangan teknologi dan permintaan masyarakat sebagai konsumen. Sering kali kita 
mengenalnya sebagai electronic commerce atau e-commerce, yang diadaptasi menjadi niaga elektronik atau niaga-el. Secara sederhana, Zande (2020) mendefinisikan niaga-el sebagai pembelian dan penjualan barang atau jasa melalui internet, dan transfer uang, serta data untuk menyelesaikan penjualan. Selanjutnya, mulai dari pekerja lepas hingga bisnis kecil sampai perusahaan terbesarpun mampu untuk menjual barang dan layanan mereka secara daring.

Grieger (2003) menyatakan bagaimana esensi pasar dari sejarahnya hingga era teknologi saat ini. Inti dari pasar ialah tempat bertemunya penjual dengan pembeli ditempat dan waktu yang sama. Saat ini pun, aktivitas tersebut tetap terjadi. Adanya evolusi teknologi yang diikuti juga dengan pembatasan ruang dan waktu yang semakin melemah dan mulai tergantikan dengan dunia maya sebagai titik pertemuan, memunculkan lokapasar daring. Uniknya, fitur dalam lokapasar tersebut membawa banyak penjual dan pembeli secara bersama-sama dalam dunia virtual. Inilah gambaran lokapasar daring yang bermunculan di belahan dunia. Jadi apabila kita bandingkan dengan niaga-el, berarti lokapasar daring adalah tempat (secara virtual) dimana transaksi pembeli dan penjual secara daring (niaga-el) terjadi. (Sirclo, 2020) mencatat pengguna niaga-el di Indonesia meningkat pesat selama tahun 2020 sebesar $18,1 \%$ atau 98,3 juta transaksi, dimana 12 juta merupakan pengguna baru. Apabila dibandingkan dengan kondisi normal, titik tersebut perlu setidaknya 1,5 - 2 tahun untuk mencapainya. Data tersebut menunjukkan jika ada proyeksi yang menarik terkait pangsa pasar di Indonesia.

Belum lagi semakin menjamurnya niaga-el dengan berbagai promo dan keunggulannya. (Riyanto, 2021) menjabarkan terdapat 10 besar lokapasar yang ramai dikunjungi se-Asia Tenggara, Shopee menduduki peringkat pertama, diikuti oleh Lazada, Tokopedia, Bukalapak, Tiki, Blibli, Sendo, Zalora, Qoo10, dan Amazon. Ketiga pemimpin pasar tersebut (Shopee, Lazada dan Tokopedia) memang selalu bersaing ketat. Meskipun Shopee unggul dikawasan area Asia Tenggara, nyatanya pengunjung Tokopedia lebih tinggi dibandingkan Shopee selama tiga bulan awal ditahun 2021 (Jayani, 2021). Tokopedia dikunjungi oleh 135,1 juta dan Shopee mendapatkan 127,4 juta kunjungan. Sedangkan Lazada berada diurutan ke-4 dengan kunjungan sebanyak 30,5 juta saja. Menariknya, data dalam Google play store per 18 Juli 2021 tercatat aplikasi Lazada dan Shopee telah 
terunduh sebanyak lebih dari 100 juta kali. Sangat kontras dengan aplikasi Tokopedia yang telah terunduh hanya lebih dari 50 juta kali. Ini menguatkan begitu derasnya persaingan diantara mereka. Sehingga akan menarik saat penelitian ini ingin mengungkap faktor-faktor apa yang telah dijalankan oleh ketiga lokapasar tersebut dalam menarik pembeli. Oleh karena itu, ketiga lokapasar tersebut dipilih menjadi obyek dalam penelitian ini.

Semakin maraknya promo yang digencarkan oleh para lokapasar daring dalam memancing pengguna tidak dapat dipungkiri. Media iklan yang digunakan seringkali dikenal dengan ads-kependekan dari advertisements atau iklan. Lewat iklan, pesan tersampaikan baik secara fungsional dan emosional dengan tujuan untuk dapat memberikan dampak positif terhadap niat beli tersampaikan (Zabadi et al., 2012). Selain itu, pengulangan iklan dapat meningkatkan niat beli konsumen. Beberapa putaran pertama dari iklan tersebut bertujuan untuk menciptidakan kesadaran kesadaran terhadap keberadaan produk, lalu rangkaian iklan berikutnya bertujuan untuk memunculkan niat untuk mengalami atau mencoba produk tersebut, yang selanjutnya diharapkan akan meningkatkan niat beli konsumen (Chih-Chung et al., 2012). Oleh karenanya, frekuensi menjadi elemen penting dalam promosi. Iklan memang tidak diragukan lagi dapat mempengaruhi keputusan pembelian. Baik itu iklan melalui media televisi (Khusnaeni et al., 2017) maupun media sosial (Siregar dan Widodo, 2018) dapat meningkatkan keputusan pembelian. Hal ini terbukti dengan meningkatnya transaksi niaga-el tiap tahunnya.

Tren peningkatan ternyata didominasi oleh generasi $\mathrm{Z}$ dan millenial, yaitu sebanyak 85\%. Apabila dipilah lagi, 36\% nya adalah berusia 18-35 tahun dan sisanya sebesar 49\% berusia di kisaran 26-35 tahun (Muazam, 2020). Ini juga yang dijadikan landasan dalam penentuan subjek dalam penelitian ini. Terlebih lagi, Perguruan tinggi yang berlokasi di Tangerang Raya (Kabupaten Tangerang, Kota Tangerang dan Kota Tangerang Selatan) banyak memiliki mahasiswa yang berstatus sebagai pekerja. Rentan usia mereka pun di bawah 40 tahunan. Dengan pendapatan yang mereka terima, niscaya mereka dapat membeli apa saja yang mereka inginkan. Selain itu mahasiswa lebih cepat beradaptasi dalam penggunaan teknologi, terutama ponsel (Suratriadi et al., 2019). Svobodová dan Rajchlová (2020) meyakini faktor-faktor perilaku belanja secara daring ini dapat dijadikan 
kunci untuk keberhasilan penerapan strategi niaga-el, dimana perilaku strategis bisnis niaga-el sangat dipengaruhi olehnya. Oleh karena itu, penelitian bertujuan untuk melihat preferensi lokapasar pada mahasiswa pekerja berdasarkan faktorfaktor perilaku mereka untuk membeli secara daring. Niscaya hasil penelitian dapat dijadikan strategi bagi wirausahawan untuk dapat memilih lokapasar yang tepat, terutama pada ketiga lokapasar unggulan. Faktor-faktor yang digunakan untuk mengidentifikasi perilaku pembelian secara daring pada studi ini mengacu pada (Svobodová dan Rajchlová, 2020), yaitu:

a. Sebelum pembelian:

1. Ulasan terhadap toko-el dan keluhan

Ulasan yang diperoleh oleh Toko-el dari penilaian pelanggan ataupun dari situs keluhan pelanggan (mis: mediakonsumen.com).

2. Sertifikasi dan keamanan

Sertifikasi menunjukkan keseriusan pada bisnis dan toko-el setidaknya memiliki sertifikasi (rating bintang) yang diberikan pelanggan.

3. Iklan dan Komunikasi pada jaringan sosial, chat dan jalur telepon

Demi meningkatkan pengaruh pada sosial media, toko-el perlu menyajikan dirinya pada media ini (seperti Facebook, Instagram, web chat, maupun telepon).

4. Harga produk

Salah satu faktor terpenting dalam menentukan barang adalah harga. Pelanggan akan menjadi loyal terhadap toko yang dapat memerikan harga yang menguntungkan dibandingkan toko lain.

b. Pembelian:

1. Situs web

Desain yang menyenangkan, penggunaan warna yang semestinya dan mudah diorientasikan pada situs web dan memotivasi pelanggan untuk tinggal dan berbelanja. Selain itu juga situs web juga tersedia dalam aplikasi seluler.

2. Faktor organisasi

Bermacamnya produk yang ditawarkan, baik pada kategori, kondisi, garansi dan sebagainya akan memberikan banyak pilihan. Namun dengan 
adanya fungsi penyaringan (filter) dapat mempermudah pelanggan dalam memilih produk.

3. Deskripsi produk

Bagian penting presentase produk secara daring adalah jelas dan deskripsi yang tersusun rapi dan memberikan informasi secara lengkap.

4. Metode pembayaran

Pelanggan akan menghargai pada banyaknya pilihan metode pembayaran. Pembayaran seperti cicilan seringkali menjadi pilihan saat hari-hari raya. Namun ada juga yang menyukai metode pembayaran tunai, karena tidak mau membayar ekstra untuk biaya pengiriman.

5. Jaringan toko

Faktor penting terhadap pelanggan ialah jaringan toko, dimana pelanggan dapat melihat, mencobanya, berkonsultasi, atau membeli setelahnya. Toko yang dimaksud ini adalah toko yang bergabung pada marketplaceatau lokapasar. Transportasi

Bermacamnya pilihan transportasi yang ditawarkan dalam memberikan produk pada pelanggan.

6. Diskon

Penilaian terhadap toko-el sejauh mana mereka memberikan keuntungan pada pelanggan dan memberikan penghargaan atas pembeliannya tersebut..

c. Layanan purna jual:

1. Layanan tambahan

Terkait dengan barang, hal yang penting ialah instalasi barang tersebut. Penawaran untuk pemindahan barang lama dan pemasangan produk baru dapat menjadikan toko-el menjadi eksklusif.

2. Garansi

Setiap toko-el memberikan masa garansi sesuatu dengan aturan.

\section{METODE}

Penelitian ini menggunakan metode survei-deskriptif. Jumlah responden yang menjawab kuesioner dan diterima sebanyak 159 responden. Namun setelah 
diseleksi berdasarkan kriteria yang telah peneliti tentukan, responden menjadi berjumlah 55 orang. Kriteria yang digunakan untuk menyeleksi responden, yaitu:

a. Berstatus mahasiswa sekaligus pekerja.

b. Berdomisili di Tangerang Raya, yaitu: Kota Tangerang, Kabupaten Tangerang dan Kota Tangerang Selatan.

c. Pernah berbelanja di lokapasar Lazada, Shopee dan Tokopedia

Penentuan sampel yang dilakukan pada nonprobability sampling ini ialah teknik snowball. Hal ini dilakukan peneliti dengan cara merekrut responden dan berikutnya dia merekrut teman, rekan atau partnernya dengan prinsip homogenitas. Persamaan pada responden ini sesuai karakteristik di atas.

Untuk teknik pengambilan data, peneliti menggunakan angket yang berisi 39 pernyataan dengan menggunakan likert sebagai skala pengukuran. Sedangkan pilihan jawaban sengaja dijadikan empat pilihan atau simetris, yaitu: sangat setuju, setuju, tidak setuju, dan sangat tidak setuju, tanpa adanya pilihan netral atau tidak tahu. Joshi et al. (2015) menjelaskan alasannya jika hal itu dilakukan untuk menghindari kecenderungan responden memilih netral atau tidak tahu, yang tidak dapat dimasukkan sebagai bentuk persetujuan ataukah ketidaksetujuan.

Distribusi kuesioner dilakukan secara virtual, yaitu dengan menggunakan layanan google forms. Keterbatasan akses terhadap populasi menjadikan penyebaran kuesioner via virtual (Baltar dan Brunet, 2012). Sedangkan penelitian ini menggunakan online survey tools, yang tersedia bebas secara daring. Persentase sederhana dan perhitungan frekuensi digunakan untuk menginterpretasikan pernyataan dalam kuesioner terhadap tiga lokapasar, yaitu: Lazada, Shopee dan Tokopedia.

\section{HASIL DAN PEMBAHASAN}

\section{Hasil}

Dalam penelitian ini, peneliti merefleksikan perilaku pembelian secara daring tergambar pada tabel 1 dan tersusun pernyataan-pernyataan dalam kuesioner. Pernyataan ini selanjutnya memberikan pernyataan terkait 3 lokapasar per komponen identifikasi perilaku pembelian secara daring.Ketiga belas butir pernyataan tersebut lalu ditanyakan kepada 55 mahasiswa-pekerja secara virtual. 
Pembahasan penelitian ini didasarkan pada administrasi 55 data dari kuesioner yang masuk ke dalam sistem google spreadsheets. Sebelumnya, deskripsi responden pada penelitian ini perlu untuk dijabarkan. Responden pada penelitian ini semuanya adalah mahasiswa-pekerja. Sebagian besar dari mereka baru bekerja kurang dari 2 tahun dan sisanya terbagi dengan jumlah yang sama antarayang bekerja antara 3-5 tahun dan yang telah bekerja lebih dari 5 tahun (lihat tabel 2). Ini menunjukkan gambaran responden yang memang seorang pekerja dan di sisi lain mereka juga berperan sebagai mahasiswa.

Tabel 1. Pernyataan-pernyataan dalam Kuesioner

\begin{tabular}{|c|c|}
\hline Komponen & Pernyataan \\
\hline $\begin{array}{l}\text { Ulasan toko-el dan } \\
\text { keluhan (UK) }\end{array}$ & $\begin{array}{l}\text { saya merasa mendapatkan manfaat dari adanya ulasan } \\
\text { pelanggan toko-el di Lazada/Shopee/Tokopedia }\end{array}$ \\
\hline $\begin{array}{l}\text { Sertifikasi dan keamanan } \\
\text { (SK) }\end{array}$ & $\begin{array}{l}\text { saya merasa mendapatkan manfaat dari adanya rating pada } \\
\text { toko-el di Lazada/Shopee/Tokopedia }\end{array}$ \\
\hline $\begin{array}{l}\text { Iklan dan komunikasi } \\
\text { pada jaringan sosial, chat } \\
\text { dan jalur telepon } \\
\text { (IK) }\end{array}$ & $\begin{array}{l}\text { saya sering menjumpai toko-el di } \\
\text { Lazada/Shopee/Tokopedia mengiklan pada berbagai situs } \\
\text { atau aplikasi online misal difacebook, youtube, twitter, } \\
\text { instagram dll }\end{array}$ \\
\hline Harga produk (HP) & $\begin{array}{l}\text { saya merasa harga produk pada toko-el di } \\
\text { Lazada/Shopee/Tokopedia sudah sesuai dengan kualitas } \\
\text { yang ditawarkan }\end{array}$ \\
\hline Situs web (SW) & $\begin{array}{l}\text { gambar produk yang ditampilkan pada toko-el di } \\
\text { Lazada/Shopee/Tokopedia menarik perhatian saya }\end{array}$ \\
\hline Faktor organisasi (FO) & 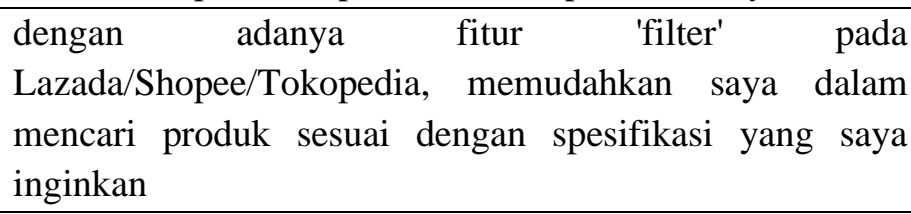 \\
\hline Deskripsi & $\begin{array}{l}\text { informasi mengenai produk yang ditawarkan melalui } \\
\text { Lazada/Shopee/Tokopedia sudah cukup akurat dan } \\
\text { lengkap }\end{array}$ \\
\hline $\begin{array}{l}\text { Metode } \\
\text { (MP) }\end{array}$ & $\begin{array}{l}\text { banyaknya pilihan metode pembayaran di } \\
\text { Lazada/Shopee/Tokopedia mempermudah saya melakukan } \\
\text { transaksi }\end{array}$ \\
\hline Jaringan toko (JT) & $\begin{array}{l}\text { saya percaya toko-el di Lazada/Shopee/Tokopedia benar- } \\
\text { benar ada toko riilnya dan melayani juga secara langsung } \\
\text { (non daring) }\end{array}$ \\
\hline Transportasi (TR) & $\begin{array}{l}\text { toko-el di Lazada/Shopee/Tokopedia memberikan saya } \\
\text { pilihan jasa pengiriman sesuai dengan keinginan saya }\end{array}$ \\
\hline Diskon (DI) & $\begin{array}{lcrr}\text { saya lebih tertarik membeli produk-produk } & \text { yang } \\
\text { ditawarkan dengan potongan harga } & \text { di } \\
\text { Lazada/Shopee/Tokopedia } & & & \end{array}$ \\
\hline
\end{tabular}




\begin{tabular}{ll}
\hline Layanan tambahan (LT) & adanya layanan tambahan (seperti tukar tambah, gratis \\
& instalasi, dan sebagainya) toko-el di \\
& Lazada/Shopee/Tokopedia membuat saya semakin yakin \\
& bertransaksi di toko tersebut \\
\hline Garansi (GA) & saya percaya toko-el di Lazada/Shopee/Tokopedia selalu \\
& menanggapi klaim garansi produk dengan baik \\
\hline
\end{tabular}

Lalu pada tabel 3, responden didominasi oleh mahasiswa yang bekerja sebagai karyawan swasta. Sisanya terbagi atas pegawai negeri sipil atau BUMN, pekerja informal dan wiraswasta. Hal ini menunjukkan jika hampir semua latar belakang pekerjaan telah memanfaatkan lokapasar sebagai media untuk bertransaksi. Sehingga dapat ditarik gambaran jika lokapasar menyasar semua konsumen dengan berbagai jenis pekerjaan mereka.

Tabel 2. Lama bekerja responden

\begin{tabular}{ccc}
\hline Lama Bekerja & Jumlah & Persentase $(\boldsymbol{\%})$ \\
\hline $0-2$ tahun & 33 & 60 \\
\hline $3-5$ tahun & 11 & 20 \\
\hline 5 tahun & 11 & 20 \\
\hline Total & 55 & 100 \\
\hline
\end{tabular}

Tabel 3. Tingkatan jenis pekerjaan responden

\begin{tabular}{lcc}
\hline \multicolumn{1}{c}{ Pekerjaan } & Jumlah & Persentase (\%) \\
\hline Swasta & 35 & 63,6 \\
\hline PNS/BUMN & 4 & 7,3 \\
\hline Informal & 7 & 12,7 \\
\hline Wiraswasta & 9 & 16,4 \\
\hline \multicolumn{1}{c}{ Total } & 55 & 100 \\
\hline
\end{tabular}

Sedangkan apabila dilihat dari lokasi responden yang berada di area Tangerang Raya, ternyata semua kota/kabupaten yang berada di Tangerang Raya terpenuhi (lihat tabel 4). Meskipun didominasi oleh Kota Tangerang Selatan dengan lebih dari separuh, bukan berarti di kota-kota lainnya tidak aktif. Ini berarti menunjukkan jika tidak ada batasan kota/kabupaten di Tangerang Raya dalam melakukan transaksi melalui lokapasar.

Hal yang samapun juga terjadi pada sisi gender, dimana baik laki-laki maupun perempuan sama-sama aktif sebagai pengguna lokapasar. Hanya saja, perempuan memang mengungguli laki-laki dalam hal ini (lihat tabel 5). 
Tabel 4. Lokasi domisili responden

\begin{tabular}{lcc}
\hline \multicolumn{1}{c}{ Domisili } & Jumlah & Persentase (\%) \\
\hline Kota Tangerang & 10 & 18,2 \\
\hline Kota Tangerang Selatan & 32 & 58,2 \\
\hline Kabupaten Tangerang & 13 & 23,6 \\
\hline Total & 55 & 100
\end{tabular}

Tabel 5. Jenis kelamin responden

\begin{tabular}{ccc}
\hline Jenis Kelamin & Jumlah & Persentase (\%) \\
\hline Perempuan & 33 & 60 \\
\hline Laki-laki & 22 & 40 \\
\hline Total & 55 & 100
\end{tabular}

\section{Pembahasan}

Dari beberapa deskripsi responden tersebut, maka analisis data yang dilakukan tergambar sebagai berikut:

$\underline{\text { Tendensi pilihan lokapasar }}$

Di dalam tiap-tiap komponen identifikasi perilaku pembelian secara daring, penilaian dilakukan oleh responden dengan memilih empat pilihan jawaban, sebagai bentuk respon. Jika ternyata komponen yang ada baik Lazada, Shopee maupun Tokopedia dirasa memberikanpositif bagi responden, maka ia akan memilih sisi kiri dari pilihan jawaban, yaitu: sangat setuju ataupun setuju. Sebaliknya, ketika dirasa berdampak negatif, maka responden akan memilih sisi kanan dari pilihan jawaban, yaitu: tidak setuju ataupun sangat tidak setuju. Selanjutnya peneliti akan membaginya berdasarkan lokapasar: Lazada, Shopee dan Tokopedia.

a. Lazada

Dari ketiga belas komponen yang telah direspon, terlihat jika semua komponen yang ada pada Lazada dinilai positif oleh para responden karena hampir sebagian besar jawaban responden mengarah kebagian setuju dan sangat setuju. Hal ini menunjukkan bahwa Lazada mampu memenuhi kriteria yang diinginkan oleh pembeli secara daring seperti yang tampak ditabel 6. 
178 | Jurnal Pendidikan dan Kewirausahaan Vol. 9 No. 12021

Tabel 6. Identifikasi perilaku pembelian secara daring pada Lazada

\begin{tabular}{cccccccccccc}
\hline Komponen & SS & $\boldsymbol{\%}$ & S & $\boldsymbol{\%}$ & STS & $\boldsymbol{\%}$ & $\begin{array}{c}\text { T } \\
\text { S }\end{array}$ & $\boldsymbol{\%}$ & Total & $\begin{array}{c}\text { Tot } \\
\boldsymbol{\%}\end{array}$ & Ket \\
\hline UK & 30 & 54,6 & 17 & 30,9 & 2 & 3,6 & 6 & 10,9 & 55 & 100 & + \\
\hline SK & 27 & 49,1 & 21 & 38,2 & 1 & 1,8 & 6 & 10,9 & 55 & 100 & + \\
\hline IK & 36 & 65,5 & 17 & 30,9 & 1 & 1,8 & 1 & 1,8 & 55 & 100 & + \\
\hline HP & 23 & 41,8 & 22 & 40 & 9 & 16,4 & 1 & 1,8 & 55 & 100 & + \\
\hline SW & 25 & 45,5 & 21 & 38,2 & 1 & 1,8 & 8 & 14,5 & 55 & 100 & + \\
\hline FO & 32 & 58,2 & 16 & 29,1 & 1 & 1,8 & 6 & 10,9 & 55 & 100 & + \\
\hline DP & 22 & 40 & 19 & 34,6 & 1 & 1,8 & 13 & 23,6 & 55 & 100 & + \\
\hline MP & 30 & 54,6 & 20 & 36,4 & 1 & 1,8 & 4 & 7,2 & 55 & 100 & + \\
\hline JT & 24 & 43,6 & 19 & 34,6 & 2 & 3,6 & 10 & 18,2 & 55 & 100 & + \\
\hline TR & 27 & 49,1 & 21 & 38,2 & 1 & 1,8 & 6 & 10,9 & 55 & 100 & + \\
\hline DI & 23 & 41,8 & 23 & 41,8 & 1 & 1,8 & 8 & 14,5 & 55 & 100 & + \\
\hline LT & 21 & 38,2 & 24 & 43,6 & 2 & 3,6 & 8 & 14,5 & 55 & 100 & + \\
\hline GA & 24 & 43,6 & 20 & 36,4 & 9 & 16,4 & 2 & 3,6 & 55 & 100 & + \\
\hline
\end{tabular}

b. Shopee

Tidak jauh berbeda dengan Lazada, ternyata identifikasi perilaku pembelian secara daring melalui lokapasar Shopee juga terpenuhi semua. Tidak ada satupun komponen yang dinilai negatif oleh responden. Bahkan pada tabel 7 nampak kontras dimana kecenderungan responden memberikan nilai positif (memilih SS dan S) sangat jomplang dibandingkan nilai negatif (STS dan TS).

c. Tokopedia

Hasil serupa juga ternyata muncul pada penilaian terhadap Tokopedia. Responden memberikan skor positif terhadap komponen identifikasi pembelian secara daring yang ada pada Tokopedia. Sebagian besar responden memilih sisi kiri (SS dan S) sebagai gambaran penilaian positif (lihat tabel8). Ini dapat ditafsirkan bahwa komponen untuk mengidentifikasi perilaku pembelian secara daring pada Tokopedia terpenuhi semua. Hal ini tentu saja menarik karena ketiga lokapasar tersebut ternyata sama-sama telah mampu memenuhi keinginan konsumen untuk membeli secara daring. 
179 | Jurnal Pendidikan dan Kewirausahaan Vol. 9 No. 12021

Tabel 7. Identifikasi perilaku pembelian secara daring pada Shopee

\begin{tabular}{cccccccccccc}
\hline Komponen & SS & \multirow{2}{*}{ S } & \% & STS & $\boldsymbol{\%}$ & $\begin{array}{c}\text { T } \\
\text { S }\end{array}$ & \% & Total & $\begin{array}{c}\text { Tot } \\
\text { \% }\end{array}$ & Ket \\
\hline UK & 37 & 67,3 & 18 & 32,7 & 0 & 0 & 0 & 0 & 55 & 100 & + \\
\hline SK & 34 & 61,8 & 20 & 36,4 & 0 & 0 & 1 & 1,8 & 55 & 100 & + \\
\hline IK & 40 & 72,7 & 13 & 23,7 & 1 & 1,8 & 1 & 1,8 & 55 & 100 & + \\
\hline HP & 30 & 54,6 & 23 & 41,8 & 0 & 0 & 2 & 3,6 & 55 & 100 & + \\
\hline SW & 32 & 58,2 & 23 & 41,8 & 0 & 0 & 0 & 0 & 55 & 100 & + \\
\hline FO & 37 & 67,3 & 14 & 25,5 & 0 & 0 & 4 & 7,2 & 55 & 100 & + \\
\hline DP & 31 & 56,4 & 18 & 32,7 & 0 & 0 & 6 & 10,9 & 55 & 100 & + \\
\hline MP & 39 & 70,9 & 15 & 27,3 & 0 & 0 & 1 & 1,8 & 55 & 100 & + \\
\hline JT & 26 & 47,3 & 22 & 40 & 3 & 5,4 & 4 & 7,3 & 55 & 100 & + \\
\hline TR & 36 & 65,5 & 16 & 29,1 & 0 & 0 & 3 & 5,4 & 55 & 100 & + \\
\hline DI & 32 & 58,2 & 19 & 34,6 & 1 & 1,8 & 3 & 5,4 & 55 & 100 & + \\
\hline LT & 33 & 60 & 18 & 32,7 & 0 & 0 & 4 & 7,2 & 55 & 100 & + \\
\hline GA & 31 & 56,4 & 18 & 32,7 & 1 & 1,8 & 5 & 9,1 & 55 & 100 & + \\
\hline
\end{tabular}

Tabel 8. Identifikasi perilaku pembelian secara daring pada Tokopedia

\begin{tabular}{cccccccccccc}
\hline Komponen & SS & \% & S & \% & STS & $\boldsymbol{\%}$ & $\begin{array}{c}\text { T } \\
\text { S }\end{array}$ & \% & Total & $\begin{array}{c}\text { Tot } \\
\text { \% }\end{array}$ & Ket \\
\hline UK & 38 & 69,1 & 16 & 29,1 & 0 & 0 & 1 & 1,8 & 55 & 100 & + \\
\hline SK & 32 & 58,2 & 21 & 38,2 & 0 & 0 & 2 & 3,6 & 55 & 100 & + \\
\hline IK & 33 & 60 & 18 & 32,8 & 1 & 1,8 & 3 & 5,4 & 55 & 100 & + \\
\hline HP & 33 & 60 & 21 & 38,2 & 0 & 0 & 1 & 1,8 & 55 & 100 & + \\
\hline SW & 29 & 52,8 & 24 & 43,6 & 0 & 0 & 2 & 3,6 & 55 & 100 & + \\
\hline FO & 38 & 69,1 & 14 & 25,5 & 0 & 0 & 3 & 5,4 & 55 & 100 & + \\
\hline DP & 28 & 50,9 & 25 & 45,5 & 0 & 0 & 2 & 3,6 & 55 & 100 & + \\
\hline MP & 31 & 56,4 & 23 & 41,8 & 0 & 0 & 1 & 1,8 & 55 & 100 & + \\
\hline JT & 26 & 47,3 & 21 & 38,2 & 3 & 5,4 & 5 & 9,1 & 55 & 100 & + \\
\hline TR & 34 & 61,8 & 19 & 34,6 & 0 & 0 & 2 & 3,6 & 55 & 100 & + \\
\hline DI & 27 & 49,1 & 25 & 45,5 & 0 & 0 & 3 & 5,4 & 55 & 100 & + \\
\hline LT & 27 & 49,1 & 24 & 43,6 & 0 & 0 & 4 & 7,3 & 55 & 100 & + \\
\hline GA & 28 & 50,9 & 24 & 43,6 & 1 & 1,8 & 2 & 3,6 & 55 & 100 & + \\
\hline
\end{tabular}

$\underline{\text { Komponen pertimbangan konsumen untuk membeli secara daring }}$

Dengan mengelompokkan jawaban responden yang positif (SS dan S) dengan negatif (TS dan STS) sesuai tabel 9, maka dapat dilihat keunggulan masingmasing lokapasar dan komponen apa saja yang ada pada ketiga lokapasar. Pengalaman responden selama melakukan niaga-el pada ketiga lokapasar tersebutmenjadi pertimbangan mereka dalam memberikan respon terhadap masing- 
masing pernyataan. Peneliti berasumsi jika respon mereka itu sebagai gambaran apa yang mereka rasakan, lihat dan lakukan selama melakukan transaksi.

Lazada memiliki keunggulan pada komponen ulasan dan keluhan (UK), Iklan dan komunikasi (IK), faktor organisasi (FO), metode pembayaran (MP), dan transportasi (TR). (Mulyadi et al., 2018) menyatidakan jika faktor kepercayaan, kemudahan dalam berinteraksi dan kualitas informasi yang diberikan oleh Lazada yang menjadikan alasan untuk melakukan pembelian. Poin utama yaitu kualitas informasi sesuai dengan hasil penelitian yang dilakukan oleh Angkat dan Prihatini (2018), dimana ulasan dan keluhan, faktor organisasi, metode pembayaran, dan transportasi menjadi bagian di dalam pemberian informasi kepada konsumen pengguna Lazada. Sedangkan Reza (2016) menjelaskan jika strategi promosi yang digunakan Lazada ialah pemanfaatan media daring. Faktor inilah yang ternyata menjadi keunggulan Lazada menurut hasil dari penelitian.

Sedangkan pada Shopee, keunggulan yang menonjol adalah komponen ulasan dan keluhan (UK), sertifikasi dan keamanan (SK), iklan dan komunikasi (IK), harga produk (HP), situs web (SW), metode pembayaran (MP), dan transportasi (TP). Saidani et al. (2019) menemukan jika ternyata kualitas situs web mempengaruhi konsumen di Jakarta untuk membeli secara beulang pada lokapasar Shopee. Ini berarti mendukung situs web menjadi salah satu keunggulan yang ada pada Shopee.Sedangkan hasil penelitian yang dilakukan oleh Hidayati(2018) menunjukkan jika online consumer review dan harga masing-masing berpengaruh terhadap keputusan pembelian melalui lokapasar Shopee di Surabaya. Ini berarti menunjukkan hasil yang sama dimana ulasan dan keluhan serta harga menjadi pertimbangan konsumen dalam bertransaksi di Shopee. Aftika et al. (2020) menambah bahwa selain review, rating (gambaran dari sertifikasi dan keamanan) juga memiliki pengaruh terhadap kepercayaan. Selanjutnya, kepercayaan inilah yang menjadikan konsumen berminat untuk membeli di lokapasar Shopee. Sertifikasi dan keamanan, meskipun tidak langsung menjadi komponen yang mempengaruhi pengguna aplikasi Shopee untuk berbelanja, tetap menjadi satu kesatuan berupa kepercayaan bersama dengan ulasan dan keluhan.

Putri dan Iriani (2019) menambahkan jika kemudahan pada penggunaan aplikasi Shopee menjadi pertimbangan konsumen dalam melakukan transaksi 
secara daring. Menurutnya salah satu kemudahan yang diperhitungkan pengguna aplikasi Shopee adalah kemudahan dalam cara pembayaran. Hasil penelitian tersebut memperkuat metode pembayaran menjadi salah satu komponen konsumen untuk bertransaksi di lokapasar Shopee. Tanca dan Lestari (2018) pula menjelaskan jika iklan Shopee mampu mempersuasi konsumen untuk berbelanja pada lokapasar Shopee, terutama pada penggunaan media televisi. Ini menjelaskan mengapa iklan menjadi komponen yang kuat pada Shopee. Terkait transportasi, yang menarik adalah penjelasan dari Fauziah (2020) dimana strategi komunikasi bisnis yang dilakukan oleh Shopee salah satunya ialah free delivery (bebas ongkos kirim). Teknik ini dapat menarik konsumen untuk menggunakan aplikasi Shopee. Sehingga komponen transportasi menjadi keunggulan Shopee dikarenakan adanya pilihan transportasi untuk tidak membayar ongkos kirim.

Berikutnya Tokopedia memiliki keunggulan pada komponen ulasan dan keluhan (UK), sertifikasi dan keamanan (SK), harga produk (HP), deskripsi produk (DP), dan transportasi (TR). Sudjatmika (2017) menemukan adanya korelasi serentidak antara harga, ulasan produk, kemudahan dan keamanan terhadap keputusan pembelian pada lokapasar Tokopedia.Nurul et al. (2019) menjelaskan jika faktor terpenting pada penjualan melalui lokapasar Tokopedia adalah ulasan merupakan faktor terpenting dibandingkan jumlah pengunjung, reputasi produk dan gold badge. Ini berarti mendukung jika ulasan dan keluhan pada Tokopedia merupakan komponen unggul. Arifuddin dan Suwasono (2020) menambahkan adanya rangsangan pemasaran yang menarik konsumen untuk membeli melalui lokapasar Tokopedia.

Rangsangan itu antara lain: produk lengkap dan praktis, harga yang murah, pengiriman yang cepat dengan banyak pilihan, banyaknya promo menarik, respon penjual yang baik dengan review dan foto yang terlihat, dan proses cepat sesuai harapan. Ini menunjukkan kewajaran jika keunggulan pada Tokopedia berupa harga produk, deskripsi produk dan transportasi. Penelitian dari Arbaini et al. (2020) pula menjelaskan adanya pengaruh rating dan review terhadap keputusan untuk membeli di lokapasar Tokopedia. Ini menunjukkan tidak dapat dipungkiri sertifikasi dan keamanan, dan ulasan menjadi komponen penting pada Tokopedia. 
Tabel 9. Persentase Tendensi Respon

\begin{tabular}{|c|c|c|c|c|c|c|c|c|c|c|c|c|c|c|c|c|}
\hline \multicolumn{2}{|c|}{ Komponen } & \multirow{3}{*}{$\begin{array}{l}\text { UK } \\
85,5\end{array}$} & \multirow{3}{*}{$\begin{array}{l}\text { SK } \\
87,\end{array}$} & \multirow{3}{*}{$\begin{array}{l}\text { IK } \\
96,\end{array}$} & \multirow[t]{2}{*}{ HP } & \multirow[t]{2}{*}{ SW } & \multirow[t]{2}{*}{ FO } & \multirow[t]{2}{*}{ DP } & \multirow[t]{2}{*}{ MP } & \multirow[t]{2}{*}{ JT } & \multirow[t]{2}{*}{ TR } & \multirow[t]{2}{*}{ DI } & \multirow[t]{2}{*}{$\mathbf{L T}$} & \multirow[t]{2}{*}{ GA } & Rata & \multirow[t]{2}{*}{ Unggul } \\
\hline & & & & & & & & & & & & & & & 2 & \\
\hline \multirow[t]{5}{*}{ Lazada } & $\mathrm{S}$ & & & & 81 & 83,7 & 87,3 & 74 & $91 \%$ & 78,2 & 87,3 & 83,6 & 81,8 & $80 \%$ & 84,5 & UK, IK, \\
\hline & & $\%$ & $2 \%$ & $4 \%$ & $8 \%$ & $\%$ & $\%$ & $6 \%$ & & $\%$ & $\%$ & $\%$ & $\%$ & & $\%$ & $\mathrm{FO}, \mathrm{MP}$, \\
\hline & & & & & & & & & & & & & & & & TR \\
\hline & $\mathrm{T}$ & 14,5 & 12 & 3,6 & 18 & 16,3 & 12,7 & 25 & $9 \%$ & 21,8 & 12,7 & 16,4 & 18,2 & $20 \%$ & & \\
\hline & $\mathrm{S}$ & $\%$ & $8 \%$ & $\%$ & $2 \%$ & $\%$ & $\%$ & $4 \%$ & & $\%$ & $\%$ & $\%$ & $\%$ & & & \\
\hline \multirow[t]{6}{*}{ Shopee } & $\mathrm{S}$ & 100 & 98 & 96 & 96 & 100 & 92,8 & 89 & 98,2 & 87.3 & 94,6 & 92,8 & 92,8 & 89,1 & 94,4 & UK, SK, \\
\hline & & $\%$ & $2 \%$ & $4 \%$ & $4 \%$ & $\%$ & $\%$ & $1 \%$ & $\%$ & $\%$ & $\%$ & $\%$ & $\%$ & $\%$ & $\%$ & IK, HP, \\
\hline & & & & & & & & & & & & & & & & SW, MP, \\
\hline & & & & & & & & & & & & & & & & TR \\
\hline & $\mathrm{T}$ & $0 \%$ & 1,8 & 3,6 & 3,6 & $0 \%$ & 7,2 & 10 & 1,8 & 12,7 & 5,4 & 7,2 & 7,2 & 10,9 & & \\
\hline & $\mathrm{S}$ & & $\%$ & $\%$ & $\%$ & & $\%$ & $9 \%$ & $\%$ & $\%$ & $\%$ & $\%$ & $\%$ & $\%$ & & \\
\hline \multirow{5}{*}{$\begin{array}{c}\text { Tokope } \\
\text { dia }\end{array}$} & $\mathrm{S}$ & 98,2 & 96 & 92 & 98 & 96,4 & 94,6 & 96 & 98,2 & 85,5 & 96,4 & 94,6 & 92,8 & 94,6 & 95,0 & UK, SK, \\
\hline & & $\%$ & $4 \%$ & $8 \%$ & $2 \%$ & $\%$ & $\%$ & $4 \%$ & $\%$ & $\%$ & $\%$ & $\%$ & $\%$ & $\%$ & $\%$ & HP, DP, \\
\hline & & & & & & & & & & & & & & & & TR \\
\hline & $\mathrm{T}$ & 1,8 & 3,6 & 7,2 & 1,8 & 3,6 & 5,4 & 3,6 & 1,8 & 14,5 & 3.4 & 5,4 & 7,2 & 5,4 & & \\
\hline & $\mathrm{S}$ & $\%$ & $\%$ & $\%$ & $\%$ & $\%$ & $\%$ & $\%$ & $\%$ & $\%$ & $\%$ & $\%$ & $\%$ & $\%$ & & \\
\hline \multirow[t]{8}{*}{ Justifikasi } & & Shop & Sho & Laz & Tok & Shop & Tok & Tok & Shop & Shop & Tok & Tok & Shop & Tok & & Ketiga \\
\hline & & ee & pee & ada & ope & ee & oped & ope & ee & ee & oped & oped & eeda & oped & & lokapasar \\
\hline & & ungg & ung & dan & dia & ungg & ia & dia & dan & ungg & ia & ia & $\mathrm{n}$ & ia & & memiliki \\
\hline & & ul & gul & Sho & ung & $\mathrm{ul}$ & ungg & ung & Tok & $\mathrm{ul}$ & ungg & ungg & Tok & ungg & & keunggul \\
\hline & & & & pee & gul & & $\mathrm{ul}$ & gul & oped & & $\mathrm{ul}$ & $\mathrm{ul}$ & oped & $\mathrm{ul}$ & & an pada \\
\hline & & & & ung & & & & & ia & & & & ia & & & UK dan \\
\hline & & & & gul & & & & & ungg & & & & ungg & & & TR \\
\hline & & & & & & & & & ul & & & & ul & & & \\
\hline
\end{tabular}

Dari nilai rata-rata jawaban responden pada tiap lokapasar, didapatkan Tokopedia sebesar 95,0\%, Shopee sebesar 94,4\% dan diikuti Lazada dengan 84,5\%. Hal ini menunjukkan bahwa Tokopedia mampu menyediakan komponenkomponen yang diinginkan konsumen saat pembelian secara daring. Menariknya, apabila ditelisik lebih mendalam pada ketiga lokapasar tersebut, maka didapatkan berupa potongan-potongan yang dapat menjadi satu kesamaan komponen. Dari ketiga lokapasar tersebut didapatkan komponen yang sama, yaitu: ulasan dan keluhan (UK) dan transportasi (TR). Seperti dibahas sebelumnya, baik ulasan dan 
keluhan dantransportasi selalu menjadi pertimbangan utama pada Lazada, Shopee dan juga Tokopedia.

Ulasan yang diberikan oleh pembeli sebelumnya sangat mempengaruhi minat konsumen untuk melakukan transaksi dengan toko-el tersebut atau tidak karena ulasan tersebut akan membentuk persepsi keyakinan konsumen terhadap toko-el tersebut (Auliya et al., 2017). Sedangkan pada transportasi, pilihan transportasi yang ditawarkan umumnya terkait pada dua hal: biaya pengiriman dan kecepatan barang dikirim. Biaya pengiriman yang dibebaskan menjadi pilihan utama, dimana konsumen tidak perlu ada usaha untuk menanggung beban tersebut. Ini acap kali dikenal sebagai 'bebas ongkos kirim'. Beberapa penelitian menunjukkan adanya pengaruh yang positif antara bebas ongkos kirim dengan keputusan pembelian (Ma, 2017), baik di perkotaan maupun di perdesaan (Maulana dan Asra, 2019). Lalu untuk kecepatan barang dikirim, konsumen dapat memilih pengiriman menggunakan jasa ojek daring (Nugroho, 2018) untuk pengiriman dalam kota. Itulah mengapa saat ini gratis ongkos kirim seringkali dimasukkan ke dalam promo oleh lokapasar.

\section{SIMPULAN}

Penelitian ini memang disusun secara sederhana dengan tujuan agar mudah dipahami. Namun dengan keterbatasan, data-data yang ada dapat memberikan kita beberapa informasi tentang komponen yang perlu ada pada lokapasar dengan identifikasi perilaku pembelian secara daring. Ketiga lokapasar pada penelitian ini, yaitu Lazada, Shopee dan Tokopedia, merupakan pilihan utama konsumen di Indonesia. Sehingga akan dijadikan acuan oleh lokapasar daring lainnya untuk dapat bersaing dengan ketiga lokapasar tersebut.

Hasil penelitian menunjukkan ternyata Tokopedia memiliki keunggulan dibandingkan Shopee maupun Lazada didasarkan pada rata-rata jawaban positif responden yang paling tinggi dibandingkan lainnya. Walaupun begitu, masingmasing lokapasar memiliki keunggulan komponen masing-masing. Tentu saja yang menarik adalah komponen utama yang dimiliki oleh ketiga lokapasar tersebut. Ulasan dan keluhan serta transportasi menjadi komponen yang paling diperhitungkan konsumen saat akan melakukan transaksi daring. Selanjutnya, perlu adanya penelitian lanjutan yang dapat melengkapi hasil penelitian ini. Pendekatan 
kuantitatif dan kualitatif dapat dijadikan pilihan untuk bisa menganalisis dan mengeksplorasi lebih mendalam lagi.

\section{DAFTAR PUSTIDAKA}

Aftika, S., Kartika, W., Widyasari, S., dan Sanjaya, V. F. (2020). Pengaruh Rating Review Belanja Di Shopee Terhadap Minat Beli (Studi Pada Mahasiswa Universitas Islam Negeri Raden Intan Lampung). Jurnal Manajemen Bisnis (JMB), 141149.Https://Ejournal.Stieibbi.Ac.Id/Index.Php/Jmb/Article/Download/17 $7 / 52$

Angkat, D. W., dan Prihatini, A. E. (2018). Pengaruh Kemudahan, Kualitas Informasi, Dan Kepercayaan Terhadap Keputusan Pembelian Secara Online Pada Situs Lazada. Jurnal Ilmu Administrasi Bisnis, 7(3), 441448.Https://Ejournal3.Undip.Ac.Id/Index.Php/Jiab/Article/View/21062/1 9713

Arbaini, P., Wahab, Z. dan Widiyanti, M. (2020). Pengaruh Consumer Online Rating Dan Review Terhadap Keputusan Pembelian Pada Pengguna Marketplace Tokopedia. Jurnal Bisnis Dan Manajemen, 7(1).Http://Jurnal.Unmer.Ac.Id/Index.Php/Jbm/Article/Download/3897/2 202

Arifuddin, Z., dan Suwasono, E. (2020). Analisis Perilaku Konsumen Dalam Pembelian Produk Online "TOKOPEDIA." REVITALISASI: Jurnal Ilmu Manajemen, $\quad 9(1), \quad$ 87-91.Https://Ejournal.UniskaKediri.Ac.Id/Index.Php/Revitalisasi/Article/Download/1082/859/

Auliya, Z. F., Umam, M. R. K., dan Prastiwi, S. K. (2017). Online Costumer Reviews (Otrs) Dan Rating: Kekuatan Baru Pada Pemasaran Online Di Indonesia. Ebbank, 8(1), 8998.Https://Www.Ebbank.Stiebbank.Ac.Id/Index.Php/EBBANK/Article/V iewfile/112/100

Baltar, F., dan Brunet, I. (2012). Social Research 2.0: Virtual Snowball Sampling Method Using Facebook. Internet Research, 22(1), 57-74. Https://Doi.Org/10.1108/10662241211199960

Chih-Chung, C., Chang, C., Lin, L. W.-C. dan Yau-Nang (2012). The Effect Of 
Advertisement Frequency On The Advertisement Attitude-The Controlled Effects Of Brand Image And Spokesperson's Credibility. Procedia-Social And Behavioral Sciences, 57, 352359.Https://Doi.Org/10.1016/J.Sbspro.2012.09.1197

Fauziah, F. (2020). Strategi Komunikasi Bisnis Online Shop "Shoppe" Dalam Meningkatkan Penjualan. Abiwara: Jurnal Vokasi Administrasi Bisnis, $1(2)$,

53.Https://Ojs.Stiami.Ac.Id/Index.Php/ABIWARA/Article/Viewfile/792/ 439

Grieger, M. (2003). Electronic Marketplaces: A Literature Review And A Call For Supply Chain Management Research. European Journal Of Operational Research, 144(2), 280

294.Https://Core.Ac.Uk/Download/Pdf/208724007.Pdf

Hanum, Z. (2021). Kemenkominfo: 89\% Penduduk Indonesia Gunakan Smartphonetitle. Media Indonesia.

Https://Mediaindonesia.Com/Humaniora/389057/Kemenkominfo-89Penduduk-Indonesia-Gunakan-Smartphone

Hatuka, T., Zur, H., dan Mendoza, J. A. (2021). The Urban Digital Lifestyle: An Analytical Framework For Placing Digital Practices In A Spatial Context And For Developing Applicable Policy. Cities, 111, 102978.Https://Doi.Org/10.1016/J.Cities.2020.102978

Hidayati, N. L. (2018). Pengaruh Viral Marketing, Online Consumer Riviews Dan Harga Terhadap Keputusan Pembelian Shopee Di Surabaya. Jurnal $\begin{array}{llll}\text { Pendidikan Tata Niaga } \quad \text { (JPTN), } & \text { 6(2), }\end{array}$ 84.Https://Jurnalmahasiswa.Unesa.Ac.Id/Index.Php/Jptn/Article/View/24 741

Jayani, D. H. (2021). Jumlah Pengunjung Tokopedia Kalahkan Shopee Pada Kuartal I-2021. Katadata.

Https://Databoks.Katadata.Co.Id/Datapublish/2021/06/11/JumlahPengunjung-Tokopedia-Kalahkan-Shopee-Pada-Kuartal-I2021\#: :Text=Secara\%20rinci\%2C\%20jumlah\%20pengunjung\%20Toko pedia,Juta\%20pada\%20kuartal\%20I\%2D2021 
Joshi, A., Kale, S., Chandel, S., dan Pal, D. K. (2015). Likert Scale: Explored And Explained. British Journal Of Applied Science dan Technology, 7(4), 396.Https://Doi.Org/10.9734/BJAST/2015/14975

Khusnaeni, N. L., Yulianto, E., dan Sunarti, S. (2017). Pengaruh Iklan Terhadap Sikap Konsumen Serta Dampaknya Pada Keputusan Pembelian (Survei Pada Mahasiswa S1 Universitas Brawijaya Malang Pengguna Kartu Seluler Telkomsel 4g Lte Yang Pernah Melihat Iklan Telkomsel 4g Lte Versi "Nixia Gamer"). Jurnal Administrasi Bisnis, 47(2), 4956.Http://Administrasibisnis.Studentjournal.Ub.Ac.Id/Index.Php/Jab/Arti cle/View/1842/2222

Ma, S. (2017). Fast Or Free Shipping Options In Online And Omni-Channel Retail? The Mediating Role Of Uncertainty On Satisfaction And Purchase Intentions. The International Journal Of Logistics Management.Http://Dx.Doi.Org/10.1108/IJLM-05-2016-0130

Maulana, H. A., dan Asra, Y. (2019). Analisa Pengaruh Promo Gratis Ongkos Kirim Terhadap Keputusan Pembelian Pada E-Commerce Oleh Generasi Z Di Daerah Pedesaan. Inovbiz: Jurnal Inovasi Bisnis, 7(2), 162165.Https://Doi.Org/10.35314/Inovbiz.V7i2.1220

Muazam, A. (2020). Transaksi E-Commerce Didominasi Generasi Z Dan Milenial. Alinea. Https://Www.Alinea.Id/Gaya-Hidup/Transaksi-E-CommerceDidominasi-Generasi-Z-Dan-Milenial-

B1zr19woj\#: :Text=Sebanyak\%2085\%25\%20transaksi\%20dilakukan\%2 0konsumen,\%2D35\%20tahun\%20(49\%25).

Mulyadi, A., Eka, D., dan Nailis, W. (2018). Pengaruh Kepercayaan, Kemudahan, Dan Kualitas Informasi Terhadap Keputusan Pembelian Di Toko Online Lazada. Jurnal Ilmiah Manajemen Bisnis Dan Terapan, 15(2), 8794.Https://Doi.Org/10.29259/Jmbt.V15i2.6656

Nugroho, H. S. (2018). Modul Praktikum: Kewirausahaan.

Nurul, M., Soewarno, N., dan Isnalita, N. (2019). Pengaruh Jumlah Pengunjung, Ulasan Produk, Reputasi Toko Dan Status Gold Badge Pada Penjualan Dalam Tokopedia. E-Jurnal Akuntansi, 28(3), 18551865.10.24843/EJA.2019.V28.I03.P14 
Putri, N. A. R., dan Iriani, S. S. (2019). Faktor-Faktor Yang Memengaruhi Keputusan Pembelian Melalui E-Commerce Shopee. Jurnal Komunika: Jurnal Komunikasi, Media Dan Informatika, 8(2), 6977.Http://Dx.Doi.Org/10.31504/Komunika.V8i2.2391

Reza, F. (2016). Strategi Promosi Penjualan Online Lazada. Co. Id. Jurnal Kajian Komunikasi, 4(1), 63-74.Https://Doi.Org/10.24198/Jkk.V4i1

Riyanto, G. (2021). Daftar 10 Marketplace Online Paling Ramai Pengunjung Di Asia Tenggara. Kompas.

Https://Tekno.Kompas.Com/Read/2021/05/10/15270037/Daftar-10-

Marketplace-Online-Paling-Ramai-Pengunjung-Di-Asia-

Tenggara?Page $=$ All

Saidani, B., Lusiana, L. M., dan Aditya, S. (2019). Analisis Pengaruh Kualitas Website Dan Kepercayaan Terhadap Kepuasan Pelanggan Dalam Membentuk Minat Pembelian Ulang Pada Pelanggan Shopee. JRMSIJurnal Riset Manajemen Sains Indonesia, 10(2), 425444.Http://Doi.Org/10.21009/JRMSI

Sirclo. (2020). Jumlah Pengguna E-Commerce Indonesia Di Tahun 2020 Meningkat Pesat. Sirclo. Https://Www.Sirclo.Com/Jumlah-Pengguna-ECommerce-Indonesia-Di-Tahun-2020-Meningkat-Pesat/

Siregar, A. G. S., dan Widodo, A. (2018). Pengaruh Periklanan Sosial Media Terhadap Keputusan Pembelian Konsumen (Study Pada Konsumen Nasi Goreng Mafia Di Kota Bandung). Eproceedings Of Management, 5(1).Https://Openlibrarypublications.Telkomuniversity.Ac.Id/Index.Php/ Management/Article/View/6017

Sudjatmika, F. V. (2017). Pengaruh Harga, Ulasan Produk, Kemudahan, Dan Keamanan Terhadap Keputusan Pembelian Secara Online Di Tokopedia. Com. Agora, 5(1).Http://Publication.Petra.Ac.Id/Index.Php/ManajemenBisnis/Article/View/5227/4814

Suratriadi, P., Santosa, J., dan Suhaila, A. (2019). Pengaruh Kemudahan Terhadap Keputusan Pembelian Makanan Secara Online Pada Mahasiswa (Studi Kasus Mahasiswa UBSI Salemba 45 Jakarta). JURNAL PENDIDIKAN DAN KEWIRAUSAHAAN, 7(1), 28- 
188 | Jurnal Pendidikan dan Kewirausahaan Vol. 9 No. 12021

39.Https://Doi.Org/10.47668/Pkwu.V7i1.17

Svobodová, Z., dan Rajchlová, J. (2020). Strategic Behavior Of E-Commerce Businesses In Online Industry Of Electronics From A Customer Perspective. Administrative $\quad$ Sciences, 78.Https://Doi.Org/10.3390/Admsci10040078

Tanca, J. T., dan Lestari, S. B. (2018). Pengaruh Terpaan Iklan Shopee Di Televisi Dan Interaksi Reference Group Terhadap Minat Bertransaksi Secara $\begin{array}{llll}\text { Online. } & \text { Interaksi } & \text { Online, } & \text { 13- }\end{array}$ 23.https://ejournal3.undip.ac.id/index.php/interaksionline/article/download/20841/19536

Zabadi, A. M. A., Shura, M., dan Elsayed, E. A. (2012). Consumer attitudes toward SMS advertising among Jordanian users. International Journal of Marketing Studies, 4(1), 77.https://doi.org/10.5539/ijms.v4n1p77

Zande, J. (2020). What is e-commerce? Definition, Benefits, Example. The Future of Commerce. https://www.the-future-ofcommerce.com/2020/01/19/what-is-e-commerce-definition-examples/ 